\title{
REPRESENTASI NILAI PANCASILA DALAM KEBUDAYAAN BALI
}

\author{
I Gusti Agung Paramita \\ Prodi Ilmu Filsafat Hindu \\ Fakultas Ilmu Agama, Seni dan Budaya \\ Universitas Hindu Indonesia Denpasar \\ Email; paramita@unhi.ac.id
}

\begin{abstract}
ABSTRAK
Artikel ini membahas tentang representasi nilai Pancasila dalam kebudayaan Bali. Penggalian nilai Pancasila dalam kebudayaan lokal, Bali khususnya penting dilakukan, melihat ancaman disintegrasi nasional dengan munculnya aksi-aksi yang berupaya mengubah ideologi Pancasila menjadi ideologi berbasis agama. Melalui penggalian nilai Pancasila dalam kebudayaan lokal, akan memperkuat asumsi bahwa Pancasila memang lahir dari rahim kebudayaan masyarakat Indonesia. Nilai-nilai Pancasila tertanam dalam adat istiadat dan kebudayaan masyarakat Bali. Ini sekaligus menunjukkan relevansi antara nilai yang terkandung dalam Pancasila dengan kebudayaan Bali yang meliputi adat istiadat, kesosialan, agama, filsafat, dan ekonomi.
\end{abstract}

\section{Kata Kunci: Pancasila, Kebudayaan Bali}

\section{ABSTRACT}

This article discusses the representation of the value of Pancasila in Balinese culture. Exploration of the value of Pancasila in local culture, Bali is especially important, seeing the threat of national disintegration with the emergence of actions that seek to change the Pancasila ideology into a religion-based ideology. Through exploring the value of Pancasila in local culture, it will strengthen the assumption that Pancasila was indeed born from the womb of the culture of the Indonesian people. The Pancasila values are embedded in the customs and culture of the Balinese people. It also shows the relevance of the values contained in Pancasila with Balinese 
culture which includes customs, sociality, religion, philosophy, and economics.

Keywords: Pancasila, Balinese Culture

\section{PENGANTAR}

Indonesia sedang dihadapkan pada persoalan konflik sosial horizontal. Ada tarik menarik kepentingan antara kelompok yang menginginkan agar Indonesia sebagai Negara Islam, sebaliknya ada yang ingin mempertahankan Pancasila sebagai ideologi dan dasar Negara karena sudah sesuai dengan karakter bangsa Indonesia yang sangat heterogen baik dari segi suku, agama, etnis dan budaya. Dua gerakan ini selalu muncul dalam perhelatan-perhelatan politik tingkat nasional, bahkan dalam pemilihan Presiden dan Wakil Presiden. Ini menunjukkan bahwa, Indonesia masih sangat rentan pada persoalan-persoalan ideologis. Konflik ideologis ini selalu mewarnai politik di Indonesia.

Jika dirunut historisitas Pancasila, sejak era "Philosophisce Grondslag" Pancasila merujuk pada kesadaran awal atau syarat yang harus ada sebagai bangsa yang merdeka. Konsep filosofis tentang jiwa bangsa, cita-cita bangsa, perasaan bangsa atau bahkan filsafat bangsa telah mulai menjadi pergulatan Bung Karno sejak tahun 1925-1926. Dalam rentang waktu itu, Sukarno sudah membahas terminologi filosofis yang kelak akan menjadi konsep Philosophisce Grondslag. Artinya Pancasila di era ini berada di dalam ruang lingkup pergulatan dan penggalian ideologis di tahap awal (Riyanto 2015: 14).

Selanjutnya, Pancasila era perumusan dan zaman revolusi. Di era ini Pancasila tampil dalam perumusan verbal dan aneka uraian penjelasan. Dalam pandangan pencetusnya, Pancasila tidak hanya seperti yang ada dalam rumusan (yang kerap dipersoalkan oleh mereka yang kurang setuju). Pancasila adalah perekat bangsa Indonesia. Pancasila adalah penyelamat keutuhan bangsa.

Periode ini adalah periode pergolakan yang merupakan kelanjutan dari proses revolusi. Pergolakan yang paling mendebarkan tentu bukan sekadar perkara konflik fisik, tetapi dengan pergulatan ideologis. Kelangsungan dinamika internal para faunding father sampai pada "kesepakatan" melakukan kontrak sosial bernegara dengan menempatkan Pancasila dan istilah Bhineka Tunggal Ika sebagai ideologi dan dasar bernegara.

Sesanti Bhineka Tunggal Ika diambil dari salah satu bait kakawin Sutasoma karya Mpu Tantular yang di dalamnya berisi tentang persatuan antara ajaran Siwa-Budha di Nusantara. Meskipun tidak banyak yang 
mengungkap secara benderang, bahwa persatuan kedua ajaran tersebut dijarit oleh benang-benang Tantra.

Aktualisasi nilai Pancasila menjadi sangat politis sejak era orde baru atau era Pasca-Soekarno. Orde baru menandai sebuah peradaban pembangunan yang diusung sedemikian rupa sehingga Pancasila seolah menjadi modelnya. Istilah ekonomi Pancasila, pendidikan Pancasila, Petani Pancasila dan seterusnya mengemuka di era ini.

Pada saat itu, Pancasila tampil dalah wajah sangat doktrinal yang disampaikan di ruang kelas, penataran pejabat, dan menjadi bahan 'kotbah' di rumah ibadah. Di lain pihak, seiring dengan penguatan nilai Pancasila, kekuasaan orde baru semakin kokoh dan represif, khususnya pada kelompok yang dianggap anti-Pancasila (Peristiwa 30 September 1965 adalah dampaknya). Di sini Pancasila dimaknai sebagai ideologi yang bertentangan dengan ideologi lainnya.

Menurut Riyanto (2015: 16), studi mengenai Pancasila memang cukup bergairah di era Orde Baru, namun memiliki tujuan politis yakni melanggengkan kekuasaan pemerintah, sehingga kritik dan pemahaman kritis terhadap kehidupan berbangsa dan bernegara tidak mendapatkan ruang. Jika bisa saya katakan, era orde baru menjadikan Pancasila sebagai instrument hegemoni dengan cita-cita yang sangat jelas: pelanggengan kekuasaan.

Perbedaan konstelasi politik tampak pada era reformasi atau pascareformasi. Pada era ini Indonesia berada pada masalah keutuhan wilayah. Di beberapa tempat konflik yang didasarkan pada identitas primordial - suku, ras dan agama bermunculan. Aksi menuntut kemerdekaan wilayah dilakukan (salah satunya kemerdekaan Timor-Timur) - Indonesia benar-benar mengalami tantangan internal yang cukup serius. Idiom-idiom persatuan di dalam Pancasila seperti tidak bertuah. Suara-suara lokal yang lama dibungkam mendapatkan saluran eskpresif. Kata sakti Bhineka Tunggal Ika tidak mampu meredam gejolak kebhinekaan bangsa.

Rezim kebebasan berekspresi yang hadir bersamaan dengan perkembangan kapitalisme global membawa resiko transformasi sosial kultural yang luar biasa. Perkembangan media massa berlangsung sangat cepat. Akses masyarakat terhadap pemikiran-pemikiran dunia sangat terbuka, ideologi-ideologi yang berbasis agama mulai bermunculan. Hal ini memicu gerakan redefinisi identitas dan ideologis di kalangan pemeluk agama.

Pancasila sebagai ideologi mulai digugat, kelompok organisasi agama secara terang-terangan ingin mendirikan Negara agama. Gerakan agama yang radikal bermunculan dan mengekspresikan diri dalam bentuk aksi terorisme. Kepedihan terhadap aksi teror ini dirasakan sangat mendalam di Bali. Aksi bom Bali I dan II masih tertanam dalam benak terdalam masyarakat Bali.

Peristiwa ini berbuah pada perubahan tipologi dan karakteristik orang Bali, sehingga muncul sikap reaktif, defensif, dan reduktif terhadap orang 
luar Bali khususnya pendatang Islam. Gejala menguatnya sikap defensifprotektif yang inward looking itu kelihatan, misalnya dalam jargon Ajeg Bali dengan budaya siaga, khususnya pasca teror bom mengguncang Bali (Nordholt, 2010: 100, Dwipayana 2010: 66-83).

Memang jejak kepedihan akibat teror tidak selesai di Bali. Aksi pemboman juga terjadi di berbagai wilayah di Indonesia dengan sasaran beragam: dari tempat-tempat yang menjadi representasi Negara barat, sampai pada tempat ibadah seperti Gereja. Kejadian terakhir adalah serangkaian aksi bom bunuh diri di tempat ibadah di Surabaya, di markas-markas kepolisian, dan penangkapan terduga teroris di salah satu kampus di Riau. Sebelumnya, Badan Nasional Penanggulangan Terorisme (BNPT) sudah membeberkan data yang mengejutkan: perguruan tinggi di Indonesia tidak steril dari radikalisme. Kampus justru menjadi tempat gerakan radikal tumbuh dan beroperasi.

Menariknya, situasi ini berdampak pada menguatnya gerakan back to Pancasila. Tidak hanya itu, Presiden Joko Widodo juga membentuk Badan Pembinaan Ideologi Pancasila (meskipun Badan ini masih menuai pro dan kontra). Di sini Pancasila terus diwacanakan, dimaknai dan disosialisasi. Bahkan perguruan tinggi menjadi salah satu sasaran dari upaya ideologisasi Pancasila tersebut.

Sayangnya pendekatan yang mengedepankan Negara sebagai subyek Pancasila sementara masyarakat sebagai obyek, tidaklah begitu efektif dalam membumikan Pancasila. Bahkan justru dikotomi ini akan menyesatkan dan memunculkan stigma: hanya Negara yang Pancasila, sehingga 'proyek' Pancasilaisasi datang dari Negara. Maka dari itu, penggalian nilai dan studi mengenai Pancasila mesti tampil dengan pemaknaan dan pendekatan baru.

Kearifan adi luhung dari kebudayaan masyarakat di Indonesia perlu disimak ulang, dikaji kembali, dikaitkan dengan Pancasila dan diaktualisasikan. Sebagaimana disampaikan Riyanto (2015: 16) nilai-nilai lokalitas dan kedaerahan tidak disimak sebagai yang "mengerdilkan" atau "menyempitkan", melainkan malah mengayakan, meluaskan, dan mengaktualisasikan cakrawala pengertian tentang nilai Pancasila.

Hal ini juga sejalan dengan riset Pranarka (1985) yang sampai pada pandangan bahwa meskipun perkembangan Pancasila saat memasuki pengaruh modern berinteraksi dengan aliran yang datang dari luar, yakni Helenisme dan Semitisme, akan tetapi subtract original kebudayaan Indonesia yang mewujud ke dalam Pancasila tetap eksis sedemikian rupa sehingga Pancasila berhasil menunjukkan diri selaku aliran pikiran keindonesiaan sendiri.

Nilai Pancasila yang hidup dalam kearifan tradisi dan budaya masyarakat diungkap kembali dengan pendekatan yang hermenutisfenomenologis, membiarkan "obyek mengungkapkan dirinya", sehingga 
Pancasila menemukan pemaknaan yang baru, tidak saja berasal dari Negara (subyek), melainkan menggali dalam kedalaman budaya masyarakat sebagaimana semangat Bung Karno ketika menggalinya. Jika Pancasila ini adalah jiwa bangsa, maka diyakini ia tertanam dalam keluhuran dan kebudayaan masyarakat.

Dalam kesempatan ini, penulis bermaksud mengkaji nilai Pancasila yang tertanam dalam kearifan dan kebudayaan masyarakat, khususnya masyarakat Bali, meskipun belum begitu mendalam, karena perlu kajian lanjutan. Studi ini dirasa penting dilakukan untuk mengecek dan menggali kembali "DNA" pikiran Pancasila dalam kebudayaan lokal masyarakat, secara spesifik masyarakat Bali. Apalagi, Notonagoro (dalam Sutrisno, 2006:6) sebelumnya pernah menyampaikan bahwa bangsa Indonesia berpancasila dalam "Tripakara", yakni dalam adat istiadat, dalam budaya, keagamaan dan dalam kenegaraan.

\section{PEMBAHASAN}

\subsection{Dinamika Pancasila dan Pandangan Dunia Jawa}

Proses pembentukan Negara Kesatuan Republik Indonesia (NKRI) berlangsung sangat panjang, melewati berbagai retret peristiwa dan dinamika politik baik secara internal maupun eskternal. Tensi dinamika internal dalam pembentukan dasar Negara misalnya, menjadi perdebatan alot, bahkan pertentangan tajam dalam sidang Badan Penyelidik Usaha-usaha Persiapan Kemerdekan Indonesia (BPUPKI) atau Dokuritzu Zyunbi Tyookasai di Gedung Tyuuo Sangi-In.

Ada kelompok yang menginginkan agar Islam harus menjadi dasar dari Negara Indonesia merdeka. Pendapat ini segera ditentang oleh kelompok yang lain, yang lebih menghendaki dasar yang sedikit banyak bersifat sekuler, misalnya prinsip kebangsaan. Perdebatan ini tidak hanya soal Islam dan bukan Islam saja. Melainkan juga perdebatan priyayi Jawa, pedagang Sumatra, petani di luar Jawa, kemudian perdebatan tentang Nasionalis, federalis dan unitarianis - semua kelompok punya gagasan sendiri-sendiri.

Soal keinginan menjadikan Islam sebagai dasar Negara, Soepomo memiliki pendapat yang berbeda. Menurut Soepomo, dilihat dari segi letak Indonesia di dunia, Indonesia mempunyai sifat yang berlainan dengan geografi negeri-negeri Irak, Iran Mesir dan Syiria, Negara-negara yang bersifat Keislaman (Corpus Islamicum). Indonesia berada di Asia Timur dan akan menjadi anggota dari lingkungan kemakmuran bersama di Asia Timur Raya. Dari lingkungan itu, anggota yang lain-lain, misalnya negeri Nippon, Tiongkok, Manchukuo, Filipina, Thai, Birma ialah bukan Negara Islam. 
Soepomo mengakui bahwa itu memang bukan alasan yang dengan sendirinya harus menolak pembentukan Negara Indonesia sebagai Negara Islam. Tetapi, kata Soepomo, itu merupakan suatu faktor yang harus dicermati juga. Bahkan ia melanjutkan bahwa di Negara-negara Islam sekalipun, misalnya Mesir, Iran dan Irak masih terdapat beberapa aliran pikiran yang masih mempersoalkan cara bagaimana menyesuaikan hukum syariah dengan kebutuhan internasional, dengan kebutuhan modern, dengan aliran zaman sekarang. Pandangan Soepomo ini sangat penting dicermati bersama.

Perdebatan pun berlangsung selama tiga hari, dari 29 Mei sampai pada tanggal 1 Juni 1945 Ir. Soekarno berpidato yang kemudian dikenal dengan sebutan Lahirnya Pancasila. Di dalam pidatonya Soekarno menawarkan jalan keluar: Indonesia merdeka bukan Negara agama, dan bukan Negara sekuler, tetapi Negara yang berdasarkan Pancasila. Pancasila seperti yang disampaikan Soekarno dirumuskan sebagai urutan berikut: (1) Kebangsaan Indonesia (2) Internasionalisme/ Perikemanusiaan (3) Demokrasi, (4) Kesejahteraan Sosial (5) Ketuhanan Yang Maha Esa. Di sini, dalam pidatonya, Soekarno menempatkan Ketuhanan Yang Maha Esa di urutan terakhir.

Rumusan Pancasila sebagai dasar Negara dianggap mewakili watak dan karakter bangsa yang multi etnik, ras, agama, dan adat istiadat. Sebagaimana disampaikan oleh Soekarno; Pancasila mewakili jiwa bangsa Indonesia. Jiwa bangsa yang digali dari dalam bangsa Indonesia itu sendiri. Kristalisasi 'jiwa bangsa' ialah sila-sila yang termaktub dalam Pancasila. Inilah sebab, Pancasila dianggap jiwa dan kepribadian bangsa Indonesia. Tanpa Pancasila, Indonesia akan menjadi bangsa yang tidak punya "Jiwa", tidak memiliki tali perekat dan pemersatu bangsa. Berikut Pernyataan Bung Karno:

"Bangsa atau rakjat adalah satu djiwa. Djangan kira seperti kursi-kursi jang disedjadjarkan. Bangsa atau rakjat mempunyai djiwa sendiri. Nah oleh karena bangsa atau rakjat adalah satu djiwa, maka kita pada waktu memikirkan dasar statis dan dinamis bangsa tidak boleh mentjari halhal di luar djiwa rakjat itu sendiri. Kalau kita mentjari hal-hal di luar djiwa rakyat itu sendiri, kandas. Ja bisa menghikmati satu dua, seratus dua ratus orang, tetapi tidak bisa menghikmati sebagai djiwa sendiri. Tiap-tiap bangsa memiliki kepribadian sendiri sebagai bangsa, tidak bisa opleggen (memaksakan) dari luar. Itu harus latent telah hidup di dalam djiwa rakyat itu sendiri. Susah mentjarinja, mana ini elemenelemen jang harus nanti total mendjadi dasar statis dan total mendjadi Letstar dinami. Ditjari-tjari, berkritalisir ke dalam lima hal ini: Ketuhanan jang Mahaesa, Kebangsaan, Peri Kemanusiaan, Kedaulatan 
Rakyat, Keadilan Sosial. Ini jang njata selali menjadi isi daripada djiwa bangsa Indonesia".

Jika dicermati retorik Bung Karno di atas, penggalian terhadap jiwa bangsa tidaklah dilakukan dengan mudah. Memerlukan kedalaman berpikir, kepekaan kultural, dan perenungan yang serius. Kepekaaan dalam mendengarkan detak jantung bangsa yang mewakili seluruh jiwa rakyat Indonesia. Penggalian Pancasila pun dilakukan dengan sangat mendalam, menembus lapis-lapis kebudayaan masyarakat, dari pra-Hindu, Hindu, Budha, Islam hingga ke budaya masa kini (Pranarka, 1985).

Sejak masa pra Hindu, Bangsa Indonesia sudah berketuhanan, berprikemanusiaan, ber-persatuan, kerakyatan dan berkeadilan. Inilah nilai dan prinsip dasar dari Bangsa Indonesia. Bisa dikatakan, rumusan Pancasila mewakili arketipe struktur ketidaksadaran kolektif bangsa dan rakyat Indonesia - yang melampaui batas-batas etnik dan agama. Di sinilah letak paralelitas antara Pancasila dengan jiwa bangsa Indonesia yang diambil dari kebudayaan dan roh kearifan lokal. Sebagaimana diafirmasi Riyanto (2015: 13) dalam Buku Kearifan Lokal dan Pancasila, kearifan lokal bangsa adalah "akar" dari Pancasila, sekaligus pohon yang kokoh rimbun penuh dengan dahan-dahan dan dedaunan lebat yang di dalamnya berlindung kupu-kupu indah dan aneka burung rupawan.

Eka Dharmaputra dalam disertasi yang berjudul Pancasila and The Search for Identity and Modernity. A. Cultural and Ethical Analysis yang kemudian diterbitkan dengan judul Pancasila: Identitas dan Modernitas (1987:80) menjelaskan bahwa nilai-nilai dalam Pancasila tidak bisa dilepaskan dari tipe-tipe religio-kultural masyarakat Indonesia khususnya pandangan dunia orang Jawa yang banyak disajikan melalui pementasan wayang.

Ada tiga karakteristik pandangan dunia Jawa yakni totalistis, dualistis, dan hierarkis. Totalistis dimaksudkan orang Jawa melihat semua kenyataan yang nampak maupun tidak nampak, sebagai bagian atau aspek, atau emanasi dari satu kesatuan menyeluruh yang disebut 'Sang Hyang Tunggal'. Semua berasal dan akan kembali kepada sangkan paran segala sesuatu.

Sementara, pandangan dunia yang dualistis berarti bahwa kesatuan dan keserasian seluruh alam semesta itu ditopang oleh interaksi yang terus menerus antara dua kekuatan yang sama dan kuatnya di alam semesta. Yaitu misalnya antara makro dan mikrokosmos, lelaki dan perempuan, kanan dan kiri, pesisir dan pedalaman, atas dan bawah dan sebagainya.

Dua kekuatan itu selalu berada dalam situasi konflik dan ketegangan satu sama lain, dan itulah yang membentuk dinamika kehidupan. Tetapi ketegangan dan konflik tersebut sekalipun diterima sebagai bagian-bagian 
yang integral dari kenyataan, harus dijaga sedemikian rupa sehingga tidak menggangu atau merusak keseimbangan.

Pandangan dunia yang ketiga adalah hierarkis. Alam kehidupan ini tidak hanya dibagi secara horizontal, melainkan juga vertikal menurut sistem hierarkis yang rumit. Seluruh kosmos terbagi-bagi dalam tingkat-tingkat. Orang Jawa memahami hierarkis ini dalam wilayah kosmik. Keserasian alam semesta dipelihara melalui norma-norma yang telah ditentukan sesuai dengan status dan tempat.

Ketiga unsur dari pandangan dunia orang Jawa yang dipaparkan Eka Dharmaputra di atas, menjadi dasar bagi sikap sinkretis pada orang Jawa. Pandangan dunia yang totalistis menyajikan keterbukaan dan keluwesan yang hampir tidak terbatas untuk menyerap apapun ke dalam sistem budaya serta sistem nilai. Pandangan dunia yang dualistis menyajikan dinamika serta penerimaan yang sadar terhadap perbedaan, bahkan konflik, selama mereka dapat dijaga keseimbanganya. Pandangan dunia hierarkis menyajikan suatu sistem yang canggih di mana segala sesuatu diberikan tempat tertentu untuk ada serta peranan tertentu untuk dilaksanakan di dalam totalitas kehidupan (Dharmaputra, 1987: 82). Tipologi pandangan dunia orang Jawa ini menurut saya tidaklah jauh berbeda dengan pandangan dunia orang Bali.

\subsection{Pancasila dan Kebudayaan Bali}

Sebagai bagian dari Bangsa Indonesia, Bali mewarisi tradisi Hinduistik yang berkembang di Nusantara dengan "lokalisasi" yang sangat kuat. Teksteks sastra Jawa Kuna yang bercorak Hindu-Budha dilestarikan dan berkembang di Bali. Sesanti Bhineka Tunggal Ika sangat aktual dalam hidup masyarakat Bali. Persatuan antara ajaran Siwa dan Budha yang disampaikan secara puitik lewat kakawin Sutasoma juga masih bertahan sampai saat ini.

Siwa-Buddha tetap hidup jejaknya bisa dirunut dari zaman raja-raja Bali kuna. Prasasti Blanjong misalnya menjelaskan, bahwa raja mencari perlindungan dari Buddha untuk kesejahteraan negerinya. Kalimat budhahsaranah krtih Balidwipa menyiratkan betapa sang raja penguasa Bali di zaman itu senantisa berlindung pada Buddha.

Ini menunjukkan sikap dan peran Bali dalam menyelamatkan peradaban besar nusantara yang memiliki semangat persatuan, selain memang Bali memiliki sistem nilai lokal sendiri yang berkembang mengikuti arus zaman.

Jika dipahami dalam konteks filosofis, masyarakat Bali memiliki nilai dasar dengan prinsip-prinsip persatuan, seperti misalnya pandangan tentang Bhuana Agung, Bhuana Alit, Rwa Bhineda, Purusa Pradana, Akasa Pertiwi, dan Ardana Iswari, Lanang Wadon. Dalam kebudayaan Bali bhuana agung 
dan bhuana alit bukanlah entitas yang bersifat dualisme-fragmentaris, melainkan dualitas yang korelasional dan berkesinambungan. Inilah yang menunjukkan karakteristik integralistik dari kebudayaan Bali - sama halnya dengan pandangan dunia Jawa yang dijelaskan di atas.

Budaya Bali cenderung melihat keseluruhan dan keutuhan sebagai sesuatu yang utama. Individu atau bhuana alit, tidak memiliki peranan sendiri yang asali, ia harus menyesuaikan diri dengan kembali pada kosmos besar - bhuana agung (Usadi, 1989, dalam Paramita, 2016: 56). Di sini keselarasan dan harmoni menjadi penting dalam relasi antara bhuana agung dan bhuana alit.

Begitu pula dengan istilah Purusa Pradana, Ardhana Iswari menjadi bermakna dan hidup dalam persatuannya. Tidak ada demarkasi yang bertentangan dalam istilah-istilah tersebut, yang satu memiliki hubungan dengan yang lain. Justru masyarakat Bali meniscayakan kesatuan dari unsurunsur yang "dual" tersebut. Pada titik ini, sesanti Bhineka Tunggal Ika sangat relevan dengan prinsip-prinsip teologis dan kosmik orang Bali.

Dalam konteks heterogenitas pemeluk agama dan kepercayaan, jika dirunut secara historis, masyarakat Bali sudah lama hidup dalam iklim yang plural dan heterogen. Goris (1974:12) misalnya mencatat di Bali terdapat 9 sekte keagamaan yang terdiri dari Siwa-Siddhanta, Pasupata, Bhairawa, Wesnawa, Boddha atau Sogata, Brahmana, Rsi, Sora, dan Ganapatya. Bahkan diperkirakan oleh Goris (1948: 3-4) pada abad ke VII berdasarkan temuan dokumen tertua di Bali - dalam hal ini di Pejeng, terdapat mantramantra agama Budha yang terkenal dengan nama ye-te-mantra yang berisikan tentang ajaran dan pesan Tathagata (Budha).

Tidak hanya prasasti yang memuat tentang agama Budha saja, di Pejeng juga ditemukan fragmen prasasti berbahasa Sansekerta dengan huruf Bali Kuno yang memberi petunjuk sifat keagamaan khususnya agama Hindu sekte Siwa. Menurut Stutterheim (dalam Astra, 1997:52) agama itu rupanya telah bersifat mantris dan tantris. Melalui temuan ini, Semadi Astra (1997) dalam disertasi berjudul Birokrasi Pemerintahan Bali Kuno Abad XII-XIII menyebutkan bahwa di daerah Pejeng pada waktu itu agama Budha dan agama Hindu sekte Siwa telah mempunyai pemeluk masing-masing yang hidup saling berdampingan. Sampai saat ini ekspresi pemujaan terhadap Siwa-Budha masih tampak.

Keluhuran hidup dalam iklim plural dan heterogen ini berlanjut sejak pemerintahan Dalem Ketut Ngulesir di Bali yang membawa abdi beragama Islam dari Majapahit ke Bali. Para abdi Raja Dalem Ketut Ngulesir tersebut tinggal di Klungklung menempati satu pemukiman dan membangun sebuah Masjid. Saban terjadi peperangan, umat Muslim ini juga terlibat membela raja. Mereka terkenal punya loyalitas. 
Sejak itulah komunitas Muslim mulai muncul di Bali dan terus berkembang, walaupun tidak sepesat di Jawa. Ketika Dalem Waturenggong menggantikan Dalem Ketut Ngulesir, perkembangan Islam di Klungkung malah makin pesat. Bahkan saat kampung Gelgel sudah tak mampu lagi menampung, kerajaan memberi tanah pelungguhan baru di Kampung Lebah. Di Klungkung sampai saat ini tercatat memiliki beberapa kampung Islam yakni Gelgel, Lebah, Kusamba dan Toya Pakeh. Spirit yang sama juga terdapat di Karangasem dengan keberadaan Saren Jawa di Desa Budakeling, Loloan di Jembrana (Paramita, 2015).

Eratnya hubungan antara umat Hindu di Bali dan pemeluk agama Islam juga tercermin melalui keberadaan pura-pura yang menggunakan nama-nama yang bernuansa Islami seperti Pura Langgar atau Pura Dalem Jawa, dan Pura Mekah. Ini menunjukkan karakteristik hribid dan sinkretik masyarakat Bali. Mereka adalah masyarakat multikultur yang hibridis, hasil dari saling silang berbagai tradisi dalam rentang waktu yang sangat panjang.

Secara sosial masyarakat Bali dikenal sebagai masyarakat komunal dengan semangat gotong royong dalam kehidupan sehari-hari. Kemanusiaan bagi orang Bali berkaitan dengan interaksi komunal - gotong royong - yang dalam rumusan Bung Karno termasuk ke dalam Eka Sila. Pada hakikatnya, masyarakat Bali menyadari swadharma "hidup bersama di dalam dunia". Selain mengakui "adanya" sendiri, manusia juga mengakui "adanya" orang lain. "Ada" bagi masyarakat Bali adalah "Ada bersama" (Mit-Sein). Manusia tidak hanya Meng-Aku, tetapi juga Meng-Kita (Driyarkara, 2006:837).

Prinsip "Ada bersama" (Mit-Sein) ini turut membangun tipologi dan karakteristik komunal orang Bali - hal ini juga teraktual melalui kultur kehidupan agraris. Karakteristik komunal orang Bali juga bisa dilihat dalam sistem kekerabatan - istilah yang digunakan untuk menunjuk kekerabatan ini, misalnya soroh, warga, krama, pasametonan serta prati sentana (Geertz, 1975), kesatuan dalam usaha bersama paiketan swagina, dan hidupnya berbagai sekaa yang merepresentasikan kesatuan minat masyarakat (Suharja, 2017:36).

Istilah sekaa ini juga lazim digunakan dalam aktivitas berkesenian orang Bali. Jadi dalam kebudayaan Bali, berkesenian juga berarti masekaa untuk mengekspresikan minat yang sama (sekaa demen). Bisa dikatakan, kesenian Bali hidup dan berkembang dengan dilandasi semangat Eka Sila: masekaa.

Jika dikategorikan kultur kesosialan orang Bali, mereka masuk ke dalam "kultur harmoni" yang berbeda dengan "kultur persona" seperti yang dilakukan di Negara-negara barat. Jika dalam kultur persona sikap-sikap individualistik berkembang dengan sangat bebas, maka dalam kultur harmoni kemasyarakatan mendapat tempat tertinggi. 
Keselarasan dalam hubungan sosial horizontal diniscayakan terjadi. Maka istilah menyama braya, semeton, mekrama, paiketan, pasemetonan yang sagilik saguluk salunglung sabayantaka, tegen bareng (dipikul bersama), nempahang rage (bisa menempatkan diri), menjadi matra dalam interaksi sosial. Prinsip kemanusiaan dalam kebudayaan Bali berhubungan dengan "kultur harmoni" dalam kehidupan sosial tersebut.

Dalam konteks adat, karakteristik komunal masyarakat Bali tercermin melalui aktivitas sosial dari tingkat tempekan, banjar, sampai pada desa adat/ pakraman. Dalam desa pakraman masyarakat Bali dikendalikan dan dibentuk oleh sistem nilai, sistem moral, sistem hukum dan sistem budaya yang menjadi kesepakatan bersama dan merupakan ekspresi kolektif suatu masyarakat.

Jadi bisa dikatakan, tindakan sosial masyarakat Bali sangat dipengaruhi oleh sistem nilai yang terkonstruksi ketika menjadi krama desa pakraman. Artinya, secara sosio-kultural-religius, masyarakat Bali dibentuk di dalam sebuah wadah bernama desa pakraman.

Prinsip-prinsip musyawarah mufakat juga diterapkan dalam desa pakraman ketika mengadakan paruman atau sangkepan berkaitan dengan agenda-agenda yang akan dilakukan. Mereka akan duduk bersama, sadu ajeng, berhadap-hadapan ketika bermusyawarah. Masyarakat Bali mengenal prinsip manusa pada, masyarakat kesamen - dalam istilah masyarakat Bali Aga di Cempaga - yang diartikan sebagai orang dengan kedudukan dan status yang sama.

Kebutuhan akan dunia sosial dan fisikal memperkuat asumsi bahwa manusia tidak dapat hidup secara baik jikalau mereka terasing dari lingkungan sosialnya. Inilah salah satu implikasi positif: kebersamaan menjadi rumah sosial orang Bali. Meskipun hidup komunal bukan tanpa resiko (seperti konflik internal), tetapi menjamin manusia tidak mengalami "keterasingan" atau "ketidakberumahan". Biasanya keterasingan dan ketidakberumahan menjadi resiko manusia yang hidup dalam "kultur persona".

Selanjutnya, dalam ranah ekonomi, masyarakat Bali menjalankan aktivitas ekonomi dengan sistem nilai yang tertuang dalam ajaran Catur Purusa Artha yakni Dharma, Artha, Kama dan Moksa. Aktivitas ekonomi dijalankan dengan prinsip-prinsip dharma. Kejujuran, keadilan, kemanusiaan dengan dibentengi doktrin karma pala menjadi acuan dalam menjalankan aktivitas ekonomi umat Hindu di Bali. Istilah pang pade payu (sama-sama jadi/mendapatkan keuntungan) yang sering didengar di pasar-pasar tradisional Bali menjadi stereotif aktivitas berdagang khas orang Bali yang mencerminkan nilai-nilai keadilan dan kemanusiaan. Dalam aktivitas ekonomi pun mereka mengdepankan "kultur harmoni" daripada "kultur persona". 


\section{PENUTUP}

Berdasarkan penjelasan tersebut dapat ditarik asumsi awal bahwa adat dan kebudayaan Bali memiliki sistem nilai yang kuat aroma dan semangat Pancasila. Adat istiadat dan kebudayaan Bali juga memiliki jiwa dan semangat Pancasialis jauh sebelum Pancasila dideklarasikan sebagai dasar bernegara oleh faunding father. Ini artinya, antara Pancasila dengan kebudayaan lokal memiliki hubungan yang sangat intim dan menunjukkan ciri khas pemikiran keindonesiaan.

Hal ini memperkuat pernyataan Bung Karno bahwa Pancasila adalah jiwa bangsa yang digali dari dalam bangsa Indonesia itu sendiri. Pancasila terlahir dari garbha kebudayaan masyarakat Indonesia. Nilai-nilai Pancasila tertanam dalam adat istiadat dan kebudayaan masyarakat Bali. Ini sekaligus menunjukkan relevansi antara nilai yang terkandung dalam Pancasila dengan kebudayaan Bali yang meliputi adat istiadat, kesosialan, agama, filsafat, dan ekonomi. Ini sekaligus memperkuat pandangan Notonagoro bahwa bangsa Indonesia berpancasila dalam adat istiadat, dalam budaya, keagamaan dan dalam kenegaraan. Gerakan membumikan Pancasila juga harus menyentuh wilayah-wilayah tersebut dan tidak hanya mendudukkan Negara sebagai subyek Pancasila.

\section{DAFTAR PUSTAKA}

\section{BUKU}

Abdulah, Irwan. 2006. Konstruksi dan Reproduksi Kebudayaan. Yogyakarta: Pustaka Pelajar.

Astra, Semadi I Gde. 1997. Birokrasi Pemerintahan Bali Kuno Abad XIIXIII. Disertasi Universitas Gadjah Mada Yogyakarta.

Bakker, SJ. 1984. Filsafat Kebudayaan, Sebuah Pengantar. Yogyakarta: Kanisius.

Budi Utama, I Wayan. 2011. Adaptasi budaya Masyarakat Bali Aga di desa Cempaga Kabupaten Buleleng dalam Merespon Regulasi Negara dalam Bidang Agama. Disertasi: Denpasar: Universitas Udayana. 
Dwipayana, AA GN Ari. Melewati Benteng Ajeg Bali. Pengantar untuk Buku Henk Schulte Nordholt, Bali: Benteng Terbuka 1955-2005, 2010.

-----------------, 2005. Globalism. Pergulatan politik Representasi atas Bali. Uluangkep.

Notonagoro. 1980. Pancasila Secara Ilmiah Populer. Dhakarta: Patjuran Tudjuh.

Nordholt, Henk Schulte. 2010. Bali Benteng Terbuka. Denpasar: Pustaka Larasan.

Paramita, I Gusti Agung. 2015. Wacana Kebudayaan dalam Dinamika Pers di Arena Politik Lokal. Tesis di Program Studi Magister Ilmu Agama dan Kebudayaan Universitas Hindu Indonesia.

Paramita, I Gusti Agung. 2016. Air, Puisi dan Industri, terbit dalam Buku Air, Tradisi dan Industri (ed) I Wayan Budi Utama. Denpasar: Pustaka Ekspresi bekerjasama dengan Pascasarjana Unhi Denpasar.

Pranarka, A.M.W. 1985. Sejarah Pemikiran Tentang Pancasila. Jakarta: Yayasan Proklramasi CSIS.

Riyanto, Armada dkk. 2015. Kearifan Lokal-Pancasila: Butir Filsafat Keindonesiaan. Yogyakarta: PT Kanisius.

Sudiarja, A. dkk. 2006. Karya Lengkap Driyarkara: Esai-esai Filsafat Pemikir yang Terlibat Penuh dalam Perjuangan Bangsanya. Jakarta: Penerbit PT Gramedia Pustaka Utama.

Suharja, Arya. 2017. Bali Mandara: Estafeta untuk Generasi Muda. Denpasar: Bappeda Litbang Provinsi Bali

Suryawan, I Ngurah. 2010. Genealogi Kekerasan dan Pergilakan Subaltern. Jakarta: Predana.

Sutrisno, Slamet. 2006. Filsafat dan Ideologi Pancasila. Yogyakarta: Penerbit Andi.

JURNAL ILMIAH http://www.dharmasmrti.com/index.php/jurnal_agama/article/view/96 